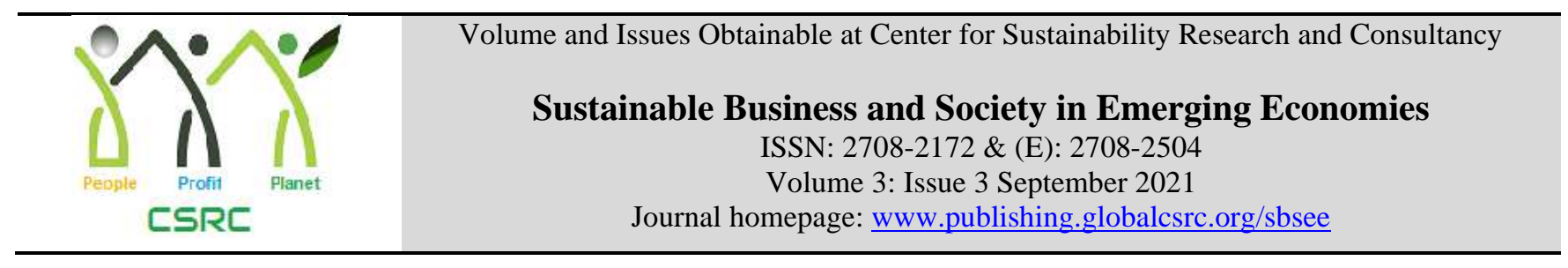

\title{
Impact of Corporate Governance on Dividend Policy: Evidence from Pakistan
}

Abdul Hameed, Ilma University, Karachi, Pakistan

*Farheen Zahra Hussain, Department of Commerce, Bahauddin Zakariya University, Multan, Pakistan Khawar Naheed, Department of Commerce, BZU, Multan, Pakistan

Muhammad Sadiq Shahid, Department of Commerce, BZU, Multan, Pakistan

*Corresponding author's email: farheenzh@gmail.com

\begin{tabular}{|c|}
\hline ARTICLE DETAILS \\
\hline $\begin{array}{l}\text { History } \\
\text { Revised format: Aug } 2021 \\
\text { Available Online: Sep } 2021\end{array}$ \\
\hline Keywords \\
\hline Government \\
\hline Delisting Risk, Political \\
\hline $\begin{array}{l}\text { Connection of Investing } \\
\text { Firms, Dividend Policy, }\end{array}$ \\
\hline Corporate Governance Index \\
\hline
\end{tabular}

JEL Classification

M40, M49

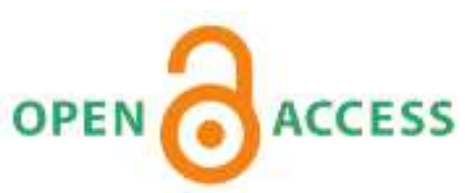

\section{ABSTRACT}

Purpose: The objective of the paper is to examine the impact of corporate governance on the dividend payout policy of firms listed on the Pakistan stock exchange during 2010-2020. As Pakistani investors face issues regarding their return in the shape of dividends and depend upon the firm's corporate governance strength. To test whether changes in firm code of corporate governance have a significant influence on dividend policy.

Design/Methodology/Approach: The panel data has been used for the period 2010-2020 and panel least square has been applied. Further, to test the association, following factors such delisting risk, government tenure, political connection with institutional shareholding as many political firms hold corporate shares which influence the decision to pay dividends.

Findings: Findings from the fixed effect model show that corporate governance has a negative impact on dividend policy while government tenure, politically connected firm has a positive impact on the dividend. The study also concludes that firm size, profitability, tax, asset turnover, leverage, and firm shareholding also influence firm dividend payment behavior.

Implications/Originality/Value: The implication of study reveals that firms must focus on strong their governance and include more independent directors on the board which leads to favorable strategies regarding investors. The investor must invest in those firm where lower political connection, pay continuous dividend either high or low decease/increase delisting chances, strong corporate governance and firm specific factors also lead to make decision of dividend payment.

(C) 2021 The authors, under a Creative Commons AttributionNonCommercial- 4.0

Recommended citation: Hameed, A., Hussain, F. Z., Naheed, K. and Shahid, M. S. (2021). Impact of Corporate Governance on Dividend Policy: Evidence from Pakistan. Sustainable Business and Society in Emerging Economies, 3 (3), 353-366.

\section{Introduction}

Distribution of firm's profits to insider and outsider shareholders is called dividend who invest in the shape 
of purchase of firms shares when firm announce self to offer share to the general public called initial public offering (IPO). Firms have two choices when firms earn profit either to retain all of their income future investment opportunity or some of the earnings are distributed to shareholders as dividends. Dividend policy is a decision to pay dividends either constant, change in dividend rate, and or not to pay a dividend in any period depending on the decision of firm's management. This decision was made by the firm board of directors as they are keen to either pay or not dividends. Payment of dividends to shareholders made either annually; a semiannually or quarterly basis depends on the size of the firm small, medium or large. Payment of dividend called dividend policy is a most important topic and one of the puzzles yet not resolved in the corporate finance from more than 60 years. This issue debate starts after the study of Modigliani \& Miller $(1958,1961)$ on the dividend relevance to the firm performance, a number of opinions have been offered on the relevance of dividends to the market prices of the firm variability and lack of relevance too. Yet, there is no consistency in the relationship of dividend on share prices increase, decrease or no change due to multiple reasons such as investment policy or dividend payout depending on the decision of the board of directors.

According to the study of Modigliani and Miller, (MM, 1961) stated that dividend has no impact on stock prices of the listed companies based upon assumptions of no taxation, perfect market capital, no asymmetric information, no cost of sale and purchase of shares and equity is the only mode of financing. On the other hand, the second school of thought demonstrates that relaxing M\&M assumptions of a perfect market, no fee charge on sale and purchase of equity, tax as well information asymmetric shows that there is a negative or positive impact on stock prices of dividend. Extensive literature reveals a number of theories developed based on the relaxation of assumptions such as the theory of tax clientele, agency theory, bird in the hand, signaling theory, and catering theory explain more about dividend phenomenon. The differences in the taxes such as the income of corporation as well as personal suggest double taxation on dividend.

Firm management and owner's conflict determines the payout policy of firm dividend behavior during any period due to conflict of interest (Jensen, 1986). Based on the above condition, management never selects that policy of dividend which does not increase their profit (Jiraporn et al. 2012). Management first decides to utilize their retained profit for the best investment option rather than paying dividends. Managers mostly work to utilize firm funds into new nosiness proposals and do work their own favors rather than focus on the wealth of owners maximizing (Jensen \& Meckling, 1976). Henceforth, improper allocation of project investment and low profitability leads to a decline investors' dividend payout. Freidman (1962) stated that firms' essential purpose is to increase the wealth and for the best interest of owners to fulfill their requirements. The sole objective of the owners is to obtain the wealth growth of the owner by a corporate manager. The study finds that managers must operate firm assets in the best interest of all shareholders such general public, employees and consumers by Freeman (1999). So reasonable prices paid by consumers as they are an end user of firms manufactured products as well as services with affordable prices. Huge Many previous studies find that there is an enormous breach regarding consumers whereas in view of maximization of stakeholder's wealth. Based on the above discussion, end users of the firm products are also part of shareholders (Ikeda et al. 2018). Price pay by consumers also display a noteworthy participation to increase firm wealth Coleman (1979). Fama \& Jensen (1983) hypothesize that corporate governance plays an important role to increase the payout of firm dividend (wealth maximization). Theory of agent described conflict among managers and firm owners or stakeholders reveals that firm cost of financing or investing rises as conflict increases which impact on firm performances. This leads to a decrease in payment of dividends to stockholders as a firm lower performs rather than dividend increases as firm performance increases due to less conflict. This leads to the maximization of firm goals through corporate governance (Shlefier \& Visheny, 1997). Veljanovski (1981) describes that efficiency to decline cost of sale is more appropriate to increase owners' profit and maximization. This objective must be attained through utilization of assets in the best way and offering less price to consumers for the purchase of the product. Conversely, the study of (Coleman, 1979) shows that this objective is not related and concerned about end users. If firms consider the final user's 
concentration about payment of the product is little concern about the primary objective. The ethical responsibility of the firms is to maximize the wealth in a way that does not affect prices. Consequently, the management of the firm must see the best utilization of resources to obtain better profit through the efficiency of cost.

There are many factors that effect on firm decision to pay dividends. Internal governance of firm and external policies about business made by the government mainly depends on tenure or political party governs the country also effect on the firm dividend. According to (Bliss \& Gul, 2012a) it is very important to understand that the politically connected firms in non-Western economies have been played a very vital role in supporting their development and success. In other words, we can understand that politically connected firms attract the researcher's attention in pressure of political connections in Asian countries (Berkman \& Galpoththage, 2016).

The present study explores the association between dividend policy and corporate governance under the new code of CG. This leads the investors as well as market analysts to focus on more changes made regarding $C G$ codes and their impact on dividend policy. This study also tests the effect of political governance tenure and the connection of firm management politically.

\section{Research Problem}

Dividend policy has been a long debate since Berle and Means (1932) and Miller and Modigliani (1961). There are multiple theories developed but yet has no consensus on this unresolved corporate finance. The primary objective of any firm is to earn profit. The distribution of profit to shareholders in the shape of dividends has income received from their investment. The payment of dividends has impact on stock market prices of the listed firms either decreased or increased. This phenomenon creates some ambiguity for investors and management of the firms due to differences in the payment of dividends or investment opportunities. There are many factors that affect stock prices but dividend policy is one of the main factors to certain market prices. To understand this problem, the researcher wants to explore the impact of the corporate index on dividend policy. Most of the developing countries such Pakistan are fronting pathetic law implementation and corruption at a high level in politically involvement (Javed \& Iqbal, 2008) deficiency of crystal clear strategy making a higher connection of political affiliation in the listed corporate firms, as well as more in family control firms (Muttakin et al. 2014). Emerging markets such as, Pakistan face a high agency problem among managers and owners' conflicts (Yusuf et al. 2018; Lau, 2009). Decisions about dividend and investment policies made by management are not in favour of stockholders especially in family-owned firms (Li \& Qian, 2013). Due to changes in process of dividend payment date decrease 3 day from 15 days changes the behavior of board by the securities exchange commission during 2017. Under the changes in the regulations for payment of dividends by corporations to their investor's act (2017), reveal that firms must pay approved dividends from the management during board meetings within 3 business days as announced. No such things happen to delay in payment of dividends to shareholders as the case approved in the board meeting (Haque, 2021). The findings of the prior studies show little and unclear evidence while comparing developed countries' market with developing countries as rights of investors has more strong rather than weak in developing countries. The firm has faced profitability decline during the recent period and pays less dividend by firms.

The objective of the current study is to find out the main factors that affect on firm dividend policy of the listed firms.

The following research question based on research problem explore in this study:

1. Is there any relationship between corporate governance and dividend policy?

2. Is there any negative association between corporate governance and dividend policy using political party tenure and delisting risk?

3. Which one factor of governance has more impact on dividend policy?

4. Does Pakistani listed firms follow a strong or weak corporate governance structure which impact on dividend decision behavior? 
5. Does politically connected firm negative on dividend policy decision?

6. Do the firm specific factors have impact on dividend policy and corporate governance?

This study is significant for academicians, investors, researchers and managers of the company regarding corporate governance and dividend policy. This study explores new paradigms of the governance pattern and their implication on Pakistani listed firms.

In this study, the limitation of published data of corporate governance has mainly lowered the sample size to get more appropriate results. Most of the company's historical data of board members, shareholding pattern not same or not published has limited the sample size of the study. Another limit is regarding less time to study and collect appropriate data.

The outline of the study has the following structure to complete this comprehensive research on corporate governance and divined policy. After a comprehensive discussion on the topic introduction, section 2, explores the literature review of the corporate governance and dividend policy with especially dividend theories. Further also developed the hypothesis based on previous literature. Section 3 describes the methodology of the study data. Study also a description of result, interpretation, a summary of result and conclusion in section 5 .

\section{Literature Review}

Dividend policy is an unresolved issue since 1932 as Berle and Means (1932). Studies more focus on dividend policy after the seminal work of Modigliani and Miller (1958) documented that dividend policy has no effect on share prices of listed firms as investment and dividend decisions already made by the management. They supported their findings based on a perfect capital market where no tax, no transaction cost, only equity is option to obtain funds and no asymmetric information to investors. Many studies have attempted the impact of dividends on share prices after the relaxation of MM (1961) assumptions. There are two schools of thought; one school focus on no impact on value still finds no reasons to not focus on this theory of irrelevant. On the other hand, the second school of thought shows that dividend has either a negative or positive effect on stock prices after the relaxation of assumptions. Dividend to pay dividend has dependent mostly on different financial variables such income earned by a company, tax payment by the corporation, and how much investment is needed for the future period. The payout policy of the corporation is also determined by the manager's interest in making the decision to investment proposal as well as many factors that relate to agency theory. The decision to pay dividend or investment policy has depended on the firm agent which knows better about the above mentioned factors and informed well creates agency conflict. This agency conflict states that agents always do not use dividend policy as wealth maximization. They prefer personal benefits rather than investors as well as owners. This shows some cost on firms regarding this agency problem and has impact on dividend payment decisions.

Nowadays many developing countries focus to ensure a better corporate governance index for better performance of the firm as the board mostly impact firm performance. In Pakistan, standards and regulations related to corporate governance amendments and made some reforms during the last two decades. Changes in the board of directors and their management occurred after the introduction of the original CG code was introduced in 2002 by SECP (Tariq \& Abbas, 2013). The primary objective of these is to improve and tackle any issue that arises between owners, management and shareholders and codes must be the same as of emerging markets such as failure to pay dividends over a long period. All the same, many firms don,t understand these codes when practically implemented in the PSX listed firms and many firms delisted from the stock exchanges. For these challenges, in 2006 (CIPE) held a conference regarding distinguishing whether codes implemented were understandable for the corporation or if there was any need to modify the codes with good explanations (Fudda, 2007). At that time, corporate governance codes change in 2021 with new changes occurring regarding accountability of directors' higher (Awan, 2014). Furthermore, the Pakistan Institute of Corporate Governance (PICG) more enriches the consciousness of corporate governance implementation quality (Salman \& Siddique, 2013). 
The introduction of the new corporate governance code 2002 suggested that only one independent director must be in board of directors, the board never consist of more than $75 \%$ of executive directors of the firms, member of the audit committee never be an executive member as well as same for chairman of the firm board should preferably be a non- executive director (SECP, 2002). On the other hand, changes suggest that in the governance code 2012 required that board should have a minimum of 1 non-executive member from any party who have higher shares in the firm, the executive directors never be more than $67 \%$ of the total number of board members, chairman of the board as well as CEO should not be the same person. These revised codes suggest that NEDs must be chairman of the firm board of director member of the audit committee specifically be a non executive directors and all members must consist of non executive as they have less influence (SECP, 2014). They also suggest that both types of directors numbers may be increased as per the requirement of the firm based on nature of the business, experience member requirements as well as for firm better communications. This may decrease the power of the executive directors and increase the interest of the directors in the favour of shareholders. The aim is to reduce the power of the executive directors and to increase the independence of the board so that the boards can be properly managed and monitored. Board diversity was not specified in the original CG Code 2002 while the revised CG code 2012 recommended gender diversity on the boards (SECP, 2002;2014). To spotlight the primary modification in the two codes $(2002 \& 2012)$ and these provisions cover six main dimensions: board evaluation, board independence, executive directors, leadership, audit committee and board diversity. Studies more focus on board size, CEO duality, independent director in the board, audit committee members, number of board meetings, audit fees, audit committee meetings. Also studies focus on the shareholding pattern of the listed firm behavior number of entities, shares total holds by firm's, individual, institutional share, foreign as well insider shareholding. In Pakistan, the most listed firms are owned by a few families except multinational firms listed in Pakistan.

Prior to M\&M (1961) study developed the hypothesis, numerous specialists accepted that with no market flaws, the more the firm delivers profit, the more it's worth increments. As indicated by the M\&M model (1958) under the ideal market suspicion the capital structure is unimportant for the financing choice of the firm, thus, inward and outer financing are amazing substitutes and profit is insignificant on the estimation of the firm.

Signaling theory suggests that firm's managers have more access to information about firm future expectations due to high insider reports they know well. They also tend to know about payment of cash dividend or not incoming period which provides signal for him as e.g., constant or increasing policy to pay a dividend. Theory of asymmetric way of information don't have enough information to shareholders about the future dividend which leads to managers can focus on trading inside of the share when he knows better information. So, the external shareholders have no such information about future predictability to increase share value as of earning management (Khan, 2016).

To find out the association between companies profitability performance, managing risk, as well as corporate governance index, mostly reveals in money related industries. This is also necessary to mitigate the information about risk and management perception regarding this in the financial sector as a "leading paradigm, supporting organizations to identify, evaluate and manage risks at the enterprise level" Anton \& Nucu (2020). It is an application for corporations, academicians, and researchers in the field based on the increasing importance of corporate governance and board characteristics in as long as comprehensive tracks for an improved monetary performance and risk acquaintance justification (Florio \& Leoni 2016), efficiency to growth in the capital (Lechner \& Gatzert 2018), and to change in prices of stock in the market due to uncertainty, that becomes stronger over time (Bunea \& Dinu (2020).

Information about the firm managing risk release is, mostly, evaluated "via annual accounts and reports by corporate entities", in acquiescence through "rules and regulations governing financial reports", mostly in the banking sectors, insurance companies as well as mutual funds (Kakanda \& Salim, 2017). Changes in the corporate governance regulations codes or practices implemented in the field and review the 
association of performance of the firms. the study also analyzed and suggest that there is no such scale to measure the risk management by many researchers (Abdullah et al. 2016; Kakanda \& Salim 2017) are the availability of committees to manage risk, their codes of conduct as well as their functional responsibility, implementation of policies and objective, and the subsistence of audit committee. Findings of the study show that there is a significant positive association normally emphasize with risk management disclosure and financial performance (Kakanda \& Salim (2017).

Mehar (2005) studies the corporate governance and payout policy of dividends of Pakistani listed firms early in the 21 st century. The findings also show that firms mostly pay dividends based on large shareholders groups rather than minority shareholders. Firms less motivated to pay minority shareholder dividend or engage minority shareholders to purchase new shares. This is a result of the tax break. Ahmed \&Javid (2009), uphold the speculation that Pakistani recorded non-monetary firms depend on both the adjustment in profits and change in net income which plainly show that the organizations depend on both current income per share and past profit per offer to set their profit installments (Khan, 2016). They contend that their examination plainly shows that profit will in general be touchier to current income than earlier profits. Moreover, they demonstrate that the possession fixation and market liquidity have a positive effect on profit pay-out strategy and market capitalization and size of the organizations have a negative effect on profit pay-out strategy which unmistakably shows that the organizations want to put resources into their resources instead of delivering profits to its investors.

The impact of the members in the board, as well as their size structure, has more concern nowadays. This also influences on the environment both internal as well as external, the situation of firms' current income, sale, assets and debt. The study also confirms that the size of board members heavily impacts on firms' current as well as last year's performance (Johl et al. 2015).

As Sheikh et al. (2013) supposed that higher number in the board has benefits because they may better knowledge as well as experience to deal things in the firms which leads to increase the performance of the firms (Elmagrhi et al. 2016). Many previous studies documents that there is no influence of member in the board. For example, higher the number of board has lower chance to decide any one point or reach a particular decision and has improper timings of boards meetings. (Cheng, 2008; Arora \& Sharma, 2016). Independent directors more focus on to protect minority shareholder rights and look after the resources used in the firm by executives (Mura, 2007), for that reason they support to diminish the problem of agency in the firm as well as secure the stakeholders interest (Froud et al. 2008). Independent director also called non executive directors have diverse backgrounds which deliver various viewpoints to the board and decreases satisfaction (Mathew et al. 2016) and also have more judgmental mixture due to the expertise (Sundarasen et al. 2016). Additionally, NEDs have their standing and profession at risk which powers them to be careful judgment to make sure that directors work in the interest of stockholders. Presence in the board of NEDs impact on firm growth in profit. They work independently and not under the stake of owners. This also gives better oversee the decisions of boards and utilization of firm resources to ensure the interests of shareholders are protected (Mura, 2007). Like other studies, Liu et al. (2015) also explain that companies with directors independent or non-executive in government ownership help to lower insider trading, increase the firm performance as well as work for a better option of investment growth.

Strategic roles of chairman as well as chief executive officer of the board have different in different companies and sectors (Doan, et al. 2020). The firm CEO is actively playing a role to run and execute all operations of the firms while chairing meetings regarding the policy of the firm in the board of directors responsible by the chairman. The duality of chairman brings taking both responsibilities by the same person called CEO duality. This creates two assumptions one called stewardship and the other called agency theory. The performance of firms depends on CEO duality because assigning more power to agents and CEO attempts to use them in the firm as a agency problem (Jensen \& Meckling, 1976; Muhammad et al. 2019). On the other hand, duality develops a good relationship and better managing officer of the firm 
as skills improve known as stewardship theory. This leads to timely decisions and more appropriate for firm better performance. As a result, high autonomy will produce firm results (Donaldson \& Davis, 1991; Bich \& Thai, 2019). Many studies did not provide the different differential impacts of powerful CEO on firm performance concerning the life-cycle of the firm.

Vafeas (1999) proved that firm core strategies impact on corporate earnings with a number of meetings held by the board of directors during any period. Their findings also suggest that board meetings impact on future investment opportunities. This is due to the interest of managers mostly fitting more as both directors inside or outside meet each other to make decisions about future projects. In addition to this, independent directors have aligned both policies and decisions for the future as well as highly monitor the policies of the managers and internal directors of the firm (Adams \& Ferreira, 2009). Demirtas (2017) authenticated that capital gains and dividend related policies are core decisions. This decision is more appropriate as firm realized that higher sales are expected or achieved during any period as directors meet before. This shows that board meetings have more impact on the dividend.

Gugler \& Yurtoglu (2003) documented the impact of companies' profit distribution to shareholders with combining governance index by utilizing the data for 1992-1998 of firms in Germany. Their study has more implications using the category of shareholdings based on majority and minority investors listed in Germany. Findings demonstrate that minority of stakeholders have less power to influence on firms to pay dividends. They conclude that firms must more focus on to protect minority shareholdings for better and transparency for both types of investors.

Nguyen et al. (2021) explore the association of payout policy of dividend with board management through Vietnam listed companies. They study the behavior of dividends with corporate governance from the period 2008-2018 using a sample of data 2,937. They used CEO duality, size of the board, independent directors, number of meetings held during each period, and gender diversity as a corporate governance index mechanism with the dividend policy of listed firms. A panel data was used for this study by applying generalized least square regression techniques on listed firms' data. Study findings show that board characteristics such as CEO duality have a negative impact on the dividend policy of listed firms in the Vietnam stock exchange. The study also shows that strong the corporate governance board of directors has lowered the payment of dividends. The study also utilized the control financial factors due to firms having a different sizes in assets, sales growth, leverage structure, and opportunities of investment also impact on firms dividend payment behavior. The study highlights that firms with feeble board governance have led to pay higher dividends to investors due to the pattern of shareholding in the firms.

Usually, the dividend is decided in the annual meeting of the board of directors (Pike \& Neale, 2009). The primary intention is to facilitate the recognition securing a reasonable payment of cash dividend in lieu of its shareholders which remain consistent with the decision of the corporate management. While preparing the distribution of dividends managers in addition to current profits also look into the expected future earnings as well. The ability of a company in maintaining a constant pay-out percentage of cash dividends in relation to maintaining a growth rate ratio in carrying weight. At the same time, the investors remain conscious of this fact as well as aspect forward for a profit increase having a positive outlook for future dividends. When a company achieves high profit in any specific year but does not expect to continue the trend in future years, it makes a regular basis of dividend and also provides supplementary dividend therefore that the investors do not get discouraged and they hope for a brighter future ahead. Under such situations, the profit is divided into two dividends. One normal and the other incremental specifying that this type of dividends is unpredicted besides may not carry on in forthcoming (DeAngelo et al. 1996).

There are more than a few alternatives for the distribution of dividends. It may be distributed in the form of a regular cash dividend or in the form of a share dividend to shareholders. They are both distributed simultaneously. Shareholders can also gain profits if the company repurchases its share while considering the regular cash dividend as common practice (Broyles, 2003). 
A number of factors govern the percentage of profits. In some cases, the law prohibits the distribution of profits unless the company is profitable deducting its reserves, the bonds, etc. It also prevents the companies from increasing the cash dividend proportion beyond some particular level to secure the interests of bondholders (Black \& Cox, 1976).

It is therefore obvious that the dividend policy is seen as the basis for differentiating between share and cash dividends through profit capitalization or may even be through buying back the shares. It happens due to the fact of fixed investment policy. As a result, the company detains profits to finance capital spending for spending and future growth or maybe even debt repayment or to distinguish the bonds. The company may also decide to distribute cash dividends and finance the deficit in capital spending and they issue new shares or through external borrowings. These alternatives in general do not affect the company's values or the wealth of shareholders under a condition of market operating characterized by ideal, efficiency and deep (Miller \& Modigliani, 1961, Black \& Scholes, 1974). If these attributes are not available one should expect arguments on impact of dividend policy, more specifically on cash dividends. This will result in the value of the company creating wealth for the shareholders.

A number of authors (Gordon, 1959, Koch and Shenoy, 1999) have criticized this policy and they are of the opinion that increases in the percentage of cash dividend increases company value, resulting in the increase in wealth of the shareholders. Some other authors like (Litzenberger \&Ramaswamy, 1979) are of the opinion that an increase in cash dividend lead to the decrease in company value resulting in the decrease in wealth of the shareholders. While Pieloch-Babiarz (2019) identifies companies' structural features also influencing their dividend distribution policy. Conversely, those whose majority shareholders participate in their management choose to retain and reinvest profits, prioritizing future returns.

An uncertain political environment may have a greater influence over business in Pakistan, since Pakistan is a transition economy and also an emerging market. Dramatic changes have occurred in Pakistan in the shape of dictatorship and democratic government in recent decades. Therefore, study examines how the political uncertainty in government changing affects corporate decision-making behaviour from the perspective of cash dividend policy. This study considers the political government tenure as a dummy variable based on period of political party government tenure.

Delisting has raised attention in recent years. This is because delisting may post a negatively direct or indirect impact on shareholders, managers, employees, firms, and other stakeholders. Therefore, the needs to understand the symptoms of financial distress in a company and to be able to predict the firm's delisting are crucial Chaiyawat \& Samranruen (2016). As delisting from stock has impact on payment of dividend. Risk of not paying dividend to shareholder impact has on profitability

Studies have shown a significant association between politically connected firm's and various firm results (Benjamin et al. 2016; Bliss \& Gul, 2012; Fung et al. 2015). the concentrated ownership creates agency problems as it allows self-dealings by controlling shareholders to go unchallenged by the board. Agency theory posits that opportunistic behavior by top managers can be constrained through effective monitoring by institutional investors (Jensen \& Meckling, 1976). Heng \& Zhang (2013) find that institutional monitoring is associated with lower R2 (higher stock price informativeness) because they can reduce manager's extraction of the firm's cash flow, while Benjamin et al. (2016) find that institutional investors can constrain the ability to expropriate shareholders' wealth through higher dividend pay-outs in Politically connected firm's. Theoretical framework for the study given below

\section{Independent Variable}

Dependent Variable

Corporate Governance (board size, duality, independent directors, number of meetings), firm specific factors, political connection, delisting risk, Government tenure, Market capitalization to GDP

Dividend Policy (dividend payout, dividend yield) 
In this study secondary data is used to test the hypothesis. A sample of 319 companies data taken from the period 2010-2020 from the state bank of Pakistan website as well as library data of published statement regarding corporate governance, stock exchange listed companies website and business recorder. This study employs annual data for all variables. This study use panel data techniques such panel fixed or random based on Hausmann test results.

\section{Summarily of the variables}

\begin{tabular}{|c|c|c|c|}
\hline Variables & Symbol & Definition & Reference \\
\hline $\begin{array}{l}\text { Dividend } \\
\text { Pay-out Ratio }\end{array}$ & DPR & $\begin{array}{l}\text { Total dividend divided by net income of } \\
\text { the firm during specific period }\end{array}$ & $\begin{array}{l}\text { Hussainey et al., (2011); Kagzi \& Guha (2018) } \\
\text { and Mirza \& Malik (2019) }\end{array}$ \\
\hline $\begin{array}{l}\text { Political } \\
\text { connected not } \\
\text { connection }\end{array}$ & PCNC & $\begin{array}{l}\text { Political connection of the directors, } \\
\text { CEO, and any other higher authority of } \\
\text { the firm's with any political party. If yes } \\
=1 \text { and No }=0\end{array}$ & $\begin{array}{l}\text { Fan, Wang, and Zhang (2007); Wu, Wu, and } \\
\text { Rui (2010); Lin et al., (2016) and Cheng and } \\
\text { Leung (2016) }\end{array}$ \\
\hline $\begin{array}{l}\text { institutional } \\
\text { shareholder }\end{array}$ & PCNC_instsh & $\begin{array}{l}\text { Total institutional shareholder } \\
\text { interaction with Political connection of } \\
\text { the firm's during specific period }\end{array}$ & Ayers et al., (2011); Chhaochhria et al., (2012). \\
\hline $\begin{array}{l}\text { Probability of } \\
\text { Delisting }\end{array}$ & Probdelist & $\begin{array}{l}\text { Delisting risk calculated using criteria if } \\
\text { firm's not pay continuous more than } 3 \\
\text { years }=1 \text { otherwise }=0\end{array}$ & Chaiyawat. T, and Samranruen, P; (2016). \\
\hline $\begin{array}{l}\text { Government } \\
\text { Tenure }\end{array}$ & Govt_tenure & $\begin{array}{l}\text { Democratic Government tenure if } \\
\text { PMLN }=1 \text { and } \mathrm{PPP}=0, \mathrm{PTI}=0\end{array}$ & \\
\hline $\begin{array}{l}\text { Market } \\
\text { Capitalization }\end{array}$ & Mkt cap & $\begin{array}{l}\text { Total market value calculated as total } \\
\text { shares multiplied by share price of the } \\
\text { specific period }\end{array}$ & Kurihara (2016) \\
\hline Mkt_GDP & & $\begin{array}{l}\text { Calculated total GDP divided by Market } \\
\text { capitalization of the firm's }\end{array}$ & $\begin{array}{l}\text { Tuomas, Ricardo \& Isabel (2011); AL- Shubiri, } \\
\text { (2010) and (Forson et al. 2013) }\end{array}$ \\
\hline $\begin{array}{l}\text { Corporate } \\
\text { Governance } \\
\text { Index }\end{array}$ & CGI & $\begin{array}{l}\text { Number of board meetings, board } \\
\text { member size, independent director in } \\
\text { board and duality (yes }=1, \mathrm{No}=0 \text { ) }\end{array}$ & $\begin{array}{l}\text { Doan (2020); Hussainey et al. (2011); Kagzi \& } \\
\text { Guha (2018); Mirza \& Malik (2019) }\end{array}$ \\
\hline $\begin{array}{l}\text { Insider } \\
\text { shareholder }\end{array}$ & INSDRSH & $\begin{array}{l}\text { Total number of share hold by the } \\
\text { insider of the firm's during specific } \\
\text { period }\end{array}$ & $\begin{array}{l}\text { Abdallah and Ismail (2017); Kumar and } \\
\text { Zattoni, (2016) }\end{array}$ \\
\hline $\begin{array}{l}\text { Individual } \\
\text { shareholders }\end{array}$ & INDSH & $\begin{array}{l}\text { Total number of share held by } \\
\text { individual }\end{array}$ & Samaha and Dahawy (2016) \\
\hline $\begin{array}{l}\text { Foreign } \\
\text { shareholder }\end{array}$ & FORSH & $\begin{array}{l}\text { Total number of share hold by foreign } \\
\text { shareholders }\end{array}$ & $\begin{array}{l}\text { Aydin \& Cavdar (2015) ; Jeon et al. (2011); } \\
\text { Mossadak et al. (2016) ; Musallam \& Lin } \\
\text { (2019); Kowerski and Wypych (2016) }\end{array}$ \\
\hline $\begin{array}{l}\text { Institutional } \\
\text { shareholders }\end{array}$ & INSTSH & $\begin{array}{l}\text { Total number of shares held by } \\
\text { institutional shareholders }\end{array}$ & $\begin{array}{l}\text { Alipour (2013); Elmagrhi et al. (2016); } \\
\text { Aggarwal et al. (2011) }\end{array}$ \\
\hline Firm Size & FSize & $\log$ of total sales & $\begin{array}{l}\text { Salih (2010); Azhagaiah \& Priya (2008); Baskin } \\
\text { (1989); Nazir et al. (2010); Hussainey et al. } \\
\text { (2011) }\end{array}$ \\
\hline Leverage & & $\begin{array}{l}\text { Total Leverage calculated debt to equity } \\
\text { of the firm's }\end{array}$ & $\begin{array}{l}\text { Nazir et al. (2010); Gul (1999); Kallapur and } \\
\text { Trombley (1999); Hussainey et al. (2011); } \\
\text { Kagzi \& Guha (2018); Mirza \& Malik (2019) }\end{array}$ \\
\hline $\begin{array}{l}\text { Asset } \\
\text { turnover }\end{array}$ & ASTO & $\begin{array}{l}\text { Total assets divided by total Revenue of } \\
\text { the firm's during period }\end{array}$ & $\begin{array}{l}\text { Hussainey et al. (2011); Kagzi \& Guha (2018); } \\
\text { Mirza \& Malik (2019) }\end{array}$ \\
\hline $\begin{array}{l}\text { Total Taxes } \\
\text { paid }\end{array}$ & Tax & $\begin{array}{l}\text { Total Taxes paid by the firm's during } \\
\text { specific period }\end{array}$ & Hussainey et al. (2011) \\
\hline
\end{tabular}

\section{Results}

Findings of the study and results interpretation based on panel data results. First study conducts Hausmann test to find out the appropriate test result either fixed or random effect model used in this study. Finding of the Hausmann test given below:

Table 4.1 Correlated Random Effects - Hausman Test
Test Summary
Chi-Sq. Statistic
Chi-Sq. d.f.
Prob.
Cross-section random $\quad 103.3067$
16
0.0000

The study result shows that data output favours the fixed effect model as chi square value 103.306 with 
prob value 0.000 less than 0.05 and random effect model is not appropriate for that data. So here we discussed and conclude the result based on fixed effect model.

\begin{tabular}{|c|c|c|c|c|}
\hline \multirow[b]{2}{*}{ Variable } & \multicolumn{3}{|c|}{ Table 4.1: Dependent Variable: DPR } & \multirow[b]{2}{*}{ Prob. } \\
\hline & Coefficient & Std. Error & $\mathrm{t}$-Statistic & \\
\hline Constant & -11.5948 & 35.6254 & -0.3254 & 0.7449 \\
\hline ASTO & 101.5573 & 23.3083 & 4.3571 & 0.0000 \\
\hline CG_IND & -1.340185 & 0.6520 & -2.0619 & 0.0298 \\
\hline FORSH & $2.46 \mathrm{E}-08$ & $5.02 \mathrm{E}-08$ & 0.4895 & 0.6245 \\
\hline GOVT_TENURE & 1.9444 & 0.3757 & 5.1743 & 0.0168 \\
\hline INDSH & 7.17E-08 & 9.93E-08 & 0.7208 & 0.4703 \\
\hline INSDRSH & $-7.95 \mathrm{E}-08$ & $3.67 \mathrm{E}-08$ & -2.0984 & 0.0332 \\
\hline INSTSH & $-3.59 \mathrm{E}-08$ & $3.01 \mathrm{E}-08$ & -1.1921 & 0.2333 \\
\hline LEVERAGE & -7.2304 & 2.5045 & -2.8763 & 0.0344 \\
\hline MKT_GDP & $2.98 \mathrm{E}-05$ & $3.68 \mathrm{E}-05$ & 0.8074 & 0.4187 \\
\hline PROBDELIST & -5.2897 & 2.4161 & -0.8247 & 0.0097 \\
\hline SIZE_S & 7.4624 & 4.0857 & 2.2029 & 0.0461 \\
\hline TAX & -0.0128 & 0.0028 & -6.0315 & 0.0024 \\
\hline PCNC_INSTSH & $3.62 \mathrm{E}-08$ & $1.67 \mathrm{E}-08$ & 2.1670 & 0.0378 \\
\hline PBT & 0.0020 & 0.0009 & 2.0977 & 0.0360 \\
\hline R-squared & 0.7549 & & & \\
\hline Adjusted R-squared & 0.7281 & & Mean dependent var & 55.1302 \\
\hline S.E. of regression & 110.5242 & & S.D. dependent var & 211.974 \\
\hline Sum squared resid & 37233117 & & Akaike info criterion & 12.3418 \\
\hline Log likelihood & -20536.12 & & Schwarz criterion & 12.9468 \\
\hline F-statistic & 28.1937 & & Hannan-Quinn criter. & 12.5581 \\
\hline Prob(F-statistic) & 0.0000 & & Durbin-Watson stat & 1.8228 \\
\hline
\end{tabular}

Results show that keeping all independent constant then dividend policy will decrease due to many other factors not taken in this study. Study results also show that asset turnover, government tenure, market to GDP, profit before tax, firm size, the interaction of political connection with institutional shareholders, foreign shareholdings, profit before tax, individual shareholders has positive and value adding factor for firm to pay more dividend while corporate governance, insider as well as institutional shareholdings, leverage, tax and probability of delist risk decrease the payout of the firm to their shareholders. Study results also show that asset turnover, corporate governance index, profit before tax, pcnc_instit shareholding, government tenure, insider shareholdings, size, tax, leverage and probability of delisting risk has a significant association with dividend policy while other variables have insignificant association with dividend policy.

F statistics value 28.19 with P-value 0.000 shows that model is a good fit as p-value less than 0.05 . This implements that dependent and independent variable have associations among them. Adjusted R2 value 0.728 shows that model explains $72.80 \%$ variation due to added independent variables and $27.20 \%$ variation unexplained due to other factors which are not taken in the study model. Model Durbin Watson value 1.82 shows that there is no autocorrelation between the independent variables.

\section{Conclusion}

Corporate governance plays an important role for any firm regarding investment and dividend decisions. The objective of the paper is to find out the internal and external factors that influence on dividend policy of firm as investors more focus on return. The study used data from 2009-2020 to test the results applying panel regression. Study results favors the fixed effect model as Haussmann test p-value is less than 0.05. Based on the findings study concludes that dividend policy depends on many factors. The corporate governance index has a negative influence on dividend policy. This also shows that firm with a lower CG index has paid lower dividends and a firm with a strong following of the new CG code has higher paying firm. Delisting also plays important role to pay dividend and results shows that continuous payment of dividend leads to decrease the delisting and vice versa. In Pakistan, political government changes after a few periods and corporate business policies depend on government tenure. They made friendly or unfriendly business policies related to their objectives. So, firm dividend policy also depends on party 
government tenure. PMLN government tenure shows in favors of business which leads to higher payments of dividend and lowers the payments of dividend in other parties' government. In Pakistan, many firms' leaders have some affiliation of political. This also negative impact on the payment of dividends due to heavy financing from the banks and relation leads to the lower payment due to lower concern about investors. In Pakistan, a politically connected firm has the influence to get loans and depends either to pay or not to pay or write off without payment due to relation with the government party. Market capitalization to GDP also has impact on firms paying dividends due to the good or bad economy of the country. Firm specific factors such as size, leverage, tax, profit before tax, and asset turnover also influence firm dividend policy.

Study implication shows that firm management must focus on strong corporate governance in the organization accordance with the need of investors which leads to increased profitability to pay higher dividend payments to lower the agency conflict. Analysts also focus on these factors and develop better choices of portfolio for their investors. The manager must focus to earn higher profits to pay more dividends leads to decrease delisting risk from the stock. Firm management lowers the connection of politically to pay more dividends and intends more about investors. This study also implication for researchers and academicians to more focus on these factors by exploring more about the governance of firm and taking higher value addition through data. The study also intends about the relationship of institutional shareholding and their nature of political relation implication on dividend policy.

Policymakers of the firm must develop policies in accordance with the objective of both investors as well as for firm owners' profit maximization.

Future studies focus on comparing the results with political and nonpolitical connected firms, adding a number of committees of each listed firm in corporate governance, distributing firms with firm size, taking non payers and payers of dividend lead to better results. Future studies also consider using more advance statistical techniques and advanced software for better results. Future studies may also use moderating variables such as investment policy to test the $\mathrm{CG}$ and dividend policy of firms in a listed stock exchange.

\section{References}

Adams, R. B., \& Ferreira, D. (2009), "Women in the boardroom and their impact on governance and performance". Journal of Financial Economics, 94, 291-309.

Ahmed, H. \& Javid, A.Y. (2009). "Dynamics and Determinants of Dividend Policy in Pakistan," Munich Personal RePEc Archive,

Aivazian, V., Booth, L., \& Cleary, S. (2003). Do emerging market firm's follow different dividend. Journal of Financial Research, 26(3), 371-387.

Alipour, M. (2013), "An investigation of the association between ownership structure and corporate performance", Management Research Review, 36(11), 1137-1166.

Al-Najjar, B. (2009). Dividend behaviour and smoothing new evidence from Jordanian panel data. Studies in Economics and Finance, 26(3), 182-197.

Al-Shattarat, K., Al-Shattrat, K., \& Hamed, R. (2018). Do dividends announcements signal future earnings changes for Jordanian firms? Journal of financial reporting and Accounting, 16(3), 417-442

Anton, G., \& Nucu, A, (2020). Enterprise Risk Management: A Literature Review and Agenda for Future Research. Journal of Risk and Financial Management, 13(11), 1-22.

Arora, A., \& Sharma, C. (2016). Corporate governance and firm performance in developing Countries: Evidence from India. The international journal of business in society, 16(2), 420-436.

Awan, R. (2014). Corporate governance and SECP: forcing out the bad", available at: http://www.brecorder.com/pages/article/1166085/2014-03-26/corporate-governance-andsecp:forcing-out-the-bad.html.

Benjamin, J., Mat Zain, M. \& Wahab, E. (2016). "Political connections, institutional investors and dividend pay-outs in Malaysia”, Pacific Accounting Review, 28, 153-179.

Berkman, H., Cole, A., \& Fu, L. (2016). Political connections and minority-shareholders protection: Evidence from securities-market regulation in China. Journal of Quantitative and Financial 
Analysis, 45(6), 1391-1417.

Berle, A., \& Means, C. (1932). The modern corporation and private property. New York: Macmillan.

Black, F. \& Scholes, M. (1974). The effects of dividend yield and dividend policy on common stock prices and returns. Journal of Financial Economics, 1(1), 1-22.

Black, F. and Cox, J. (1976) Valuing Corporate Securities: Some Effects of Bond Indenture Provisions. Journal of Finance, 31, 351-367.

Bliss, M. \& Gul, A. (2012a), "Political connections and cost of debt: some Malaysian evidence", Journal of Banking and Finance, 36, 1520-1527.

Budagaga, A.R. (2020), "Dividend policy and market value of banks in MENA emerging markets: residual income approach", Journal of Capital Markets Studies, 4(1), 25-45.

Bunea, M., \& Dinu, V. (2020). The relationship between the board's characteristics and the risk management of the Romanian banking sector', Journal of Business Economics and Management, 21(5): 1248-1268.

Chaiyawat, T. \& Samranruen, P (2016). Delisting Risk Analysis: Empirical Evidence from the Thai Listed Companies. Advances in Economics and Business, 4(8), 461 - 467.

Coleman, L. (1979). Efficiency, utility, and wealth maximization. Hofstra L. Rev., 8, 509.

DeAngelo, H., L. DeAngelo, \& Skinner (1996). Reversal of fortune: Dividend signaling and the disappearance of sustained earnings growth. Journal of Financial Economics, 40, 341-371.

Elmagrhi, H., Ntim, G. \& Wang, Y. (2016). Antecedents of voluntary corporate governance disclosure: a post-2007/08 financial crisis evidence from the influential UK Combined Code. Corporate Governance: The International Journal of Business in Society, 16(3), 507-538.

Fama, F., \& Jensen, C. (1983). Agency problems and residual claims. The journal of law and Economics, 26(2), 327-349.

Florio, C., \& Leoni, G. (2016). Enterprise Risk Management and Firm Performance: The Italian Case. The British Accounting Review, 49(1), 56-74.

Freeman, R. E. (1999). Divergent stakeholder theory. Academy of management review, 24(2), 233 - 236.

Friedman, M. (1962). Capitalism and Freedom, University of Chicago. Press, Chicago, IL. https://www.worldcat.org/title/capitalism-and-freedom/oclc/168498

Froud, J., Leaver, A., Tampubolon, G., \& Williams, K. (2008), "Everything for sale: How non-executive directors make a difference", The Sociological Review, 56, 162-186.

Fudda, M. (2007). Survey of Corporate Governance Practices in Pakistan", available at: http://www.cipe.org/blog/2007/09/04/survey-of-corporate-governance-practices-inpakistan/.

Gordon M. (1959). Dividends, earnings and stock prices. The Review of Economics and Statistics, 41(2), 99-105

Gordon M. (1962). The savings-investment and valuation of a corporation. The Review of Economics and Statistics, 44 (1), 37-51

Gordon, J. (1963). Optimal investment and financing policy. The Journal of Finance, 18(2), 264-272.

Gugler, K. \& Yurtoglu (2003). Corporate governance and dividend pay-out policy in Germany'. European Economic Review, 47, 731-756.

Haque, U. (2021, March 04). DAWN. Retrieved from https://www.dawn.com: https://www.dawn.com/news/1610556

Heng, A. \& Zhang, T. (2013). Stock price synchronicity, crash risk, and institutional investors. Journal of Corporate Finance, 21, 1-15.

Ikeda, N., Inoue, K., \& Watanabe, S. (2018). Enjoying the quiet life: Corporate decision-making by entrenched managers. Journal of the Japanese and International Economies, 47, 55- 69.

Javid, Y., \& Iqbal, R. (2008). Ownership concentration, corporate governance and firm performance: Evidence from Pakistan. The Pakistan Development Review, 643-659.

Jensen, C. (1986). Agency costs of free cash flow, corporate finance, and takeovers. The American economic review, 76(2), 323-329.

Jensen, C., \& Meckling, H. (1976). Theory of the firm: Managerial behavior, agency costs, and ownership structure. Journal of financial economics, 3(4), 305-360. 
Jiraporn, P., Kim, C., Kim, S., \& Kitsabunnarat, P. (2012). Capital structure and corporate governance quality: Evidence from the Institutional Shareholder Services. International Review of Economics \& Finance, 22(1), 208-221.

Johl, K., Kaur, S., \& Cooper, J. (2015). Board characteristics and firm performance: Evidence from Malaysian public listed firms. Journal of Economics, Business and Management, 3(2), 239-243.

Kakanda, , \& Salim, B., (2017). Corporate governance, risk management disclosure, and firm performance: a theoretical and empirical review perspective. Asian Economic and Financial Review, 7(9), 836-845.

Khan, N, U. (2011). Dividend policy and the stock market reaction to dividend announcements in Pakistan. PhD Thesis, University of Dundee.

Khan, T. (2016). 'Company dividends and ownership structure: Evidence from UK panel data'. Economic Journal, 116, 172-189.

Kim, W. S., Kiymaz, H., \& Oh, S. (2020). Do country-level legal, corporate governance, and cultural characteristics influence the relationship between insider ownership and dividend policy?. Pacific-Basin Finance Journal, 64, 101457.

Lau, J., Sinnadurai, P., \& Wright, S. (2009). Corporate governance and chief executive officer dismissal following poor performance: Australian evidence. Accounting \& Finance, 49(1), 161-182.

Lechner,P \& Gatzert, N., (2018). Determinants and value of enterprise risk management: empirical evidence from Germany. The European Journal of Finance, 24(10), 867-887

Li, J., \& Qian, C. (2013). Principal-principal conflicts under weak institutions: A study of corporate takeovers in China. Strategic Management Journal, 34(4), 498-508.

Litzenberger, R. \& K. Ramaswamy (1979). The effects of personal taxes and dividends on capital asset prices: Theory and empirical evidence'. Journal of Financial Economics, 7, 163-195.

Liu, Y., Miletkov, M., Wei, Z., \& Yang, T. (2015), "Board independence and firm performance in China". Journal of Corporate Finance, 30, 223-244.

Mathew, S., Ibrahim, S., \& Archbold, S. (2016). Boards attributes that increase firm risk - evidence from the UK", Corporate Governance: The International Journal of Business in Society, 16(2), 233-258.

Mehar, A., (2005). Impacts of equity financing on liquidity position of a firm. Applied Financial Economics, 15 (6), 425-438

Miller, M. \& Modigliani, F. (1961). Dividend policy, growth and the valuation of shares. The Journal of Business, 34(4), 411-433.

Modigliani, F. \& M. Miller (1958), 'The cost of capital, corporation finance, and the theory of investment'. American Economic Review, 48, 261-297.

Mura, R. (2007). Firm performance: Do non-executive directors have minds of their own? Evidence from UK panel data. Financial Management, 36(3), 81-112.

Muttakin, B., Khan, A., \& Subramaniam, N. (2014). Family firms, family generation and performance: evidence from an emerging economy. Journal of accounting in emerging economies.

Nguyen, C., \& Nguyen, D., (2021). The impact of operating cash flow in decision-making of individual investors in Vietnam's stock market. Journal of Asian Finance, Economics and Business, 7(5) 19 -29 .

Pieloch-Babiarz, A. (2019). Ownership structure, board characteristics and dividend policy: evidence from the Warsaw Stock Exchange. Ekonomia i Prawo. Economics and Law, 18(3): 317-330.

Pike, R., \& Neale, B., (2009). Corporate finance and Investment, Decisions and Strategies, 6th edition, Prentice Hall.

Salman, F., \& Siddiqui, K. (2013), "Corporate Governance in Pakistan: from the Perspective of Pakistan Institute of Corporate Governance", The IUP Journal of Corporate Governance, 12(4), 17-21.

Sheikh, N.A., Wang, Z., \& Khan, S. (2013), "The impact of internal attributes of corporate governance on firm performance", International Journal of Commerce and Management, 23(1), 38-55.

Sundarasen, S.D.D., Je-Yen, T. \& Rajangam, N. (2016), "Board composition and corporate social responsibility in an emerging market", Corporate Governance: The International Journal of Business in Society, 16(1), 35-53.

Tariq, B., \& Abbas, Z. (2013). Compliance and multidimensional firm performance: evaluating the 
efficacy of rule-based code of corporate governance", Economic Modelling, 35, 565-575.

Vafeas, N. (1999). Board meeting frequency and firm performance", Journal of Financial Economics, 53(1), 113-142.

Veljanovski, G. (1981). Wealth maximization, law, and ethics-On the limits of economic efficiency. International Review of Law and Economics, 1(1), 5-28.

Yusuf, F; Yousaf, A; \& Saeed, A (2018). Rethinking agency theory in developing countries: A case study of Pakistan. Accounting Forum.

Zeeshan, M, \& Abdullah, M. (2016). Capital asset price model empirical evidence from Karachi stock exchange. Journal of Research in Business and Management, 4(10), 61-67. 